\title{
Aneuploid analyses of three chlorophyll abnormalities in Emmer wheat
}

\author{
Koichiro Tsunewaki* \\ Fukui Prefectural University, 4-1-1 Kenjyojima, Matsuoka, \\ Fukui 910-1195, Japan
}

(Received 20 February 2004, accepted 17 March 2004)

\begin{abstract}
Of the various chlorophyll abnormalities that occur in polyploid wheats, genetic bases of only two types, chlorina and virescence, are known. Here, for the first time, the chromosomal bases of three other chlorophyll abnormalities, striatovirescence, delayed virescence, and albino, which occur in Emmer wheat $(2 \mathrm{n}=4 \mathrm{x}$ $=28$, genome constitution $\mathrm{AABB}$ ) are reported. A set of disomic substitution lines of Langdon durum was used for chromosome identification. All three abnormalities are controlled by two duplicated recessive genes (carrier chromosome in parentheses); striato-virescence by $s v 1$ (3A) and $s v 2(2 \mathrm{~A})$, delayed virescence by $d v 1$ (2B) and $d v 2$ (supposedly 2A), and albino by abn1 (2A) and abn2 (2B). Genes on the same chromosome are located in different loci and are recombined with each other. The Chinese Spring cultivar of common wheat $(2 \mathrm{n}=6 \mathrm{x}=42$, genome constitution AABBDD) carries wild-type homoeoalleles for these abnormalities; Sv3 (2D), Dv3 (2D), and Abn3 (2D).
\end{abstract}

Key words: albino, aneuploid analysis, delayed virescence, polyploid wheats, striato-virescence

\section{INTRODUCTION}

Two true-bred lines that have the AABB genome constitution and ne1ne1 Ne2Ne2 genotype were obtained by transferring the $\mathrm{Ne} 2$ gene (one of two complementary genes for hybrid necrosis; Tsunewaki, 1960) from the common wheat 'Jones Fife' (abbreviated JF) to the emmer wheat 'Vernal'. One line stably expressed a chlorophyll abnormality known as striato-virescence. During the genetic analysis of this abnormality, two other chlorophyll abnormalities, delayed virescence and albino, appeared. Lines fixed for the genes of those abnormalities were bred and subjected to aneuploid analysis using a set of disomic substitution lines of the durum wheat 'Langdon' (abbrev. Ldn DS lines), in which the Ldn's Aor B-genome chromosome is substituted by its D-genome homoeologue of the common wheat cultivar 'Chinese Spring' (abbrev. CS) (Joppa and Williams, 1988).

Striato-virescence was reported by Frankel (1950), but the chromosome basis of its inheritance is unknown (McIntosh et al., 1998). Delayed virescence is a new chlorophyll abnormality. Albino is a chlorophyll mutation frequently seen by wheat workers, but so far no locus has been identified for it due to the lethality of albinotic

Edited by Minoru Murata

* Corresponding author. Present address: 6-14-10 Kasugadai, Nishi-ku, Kobe 651-2276, Japan plants. Aneuploid analyses of these three chlorophyll abnormalities therefore have been made.

The findings reported here provide new information on the genetic bases of chlorophyll abnormalities in wheat. Moreover, they show the limitation of aneuploid analysis that uses DS lines for traits determined by duplicated recessive genes.

\section{MATERIALS AND METHODS}

Designation of wheat genotypes and chromosomes

The following names are used here to indicate different wheat genotypes: 'Emmer wheat' for tetraploid genotypes having the AABB genome constitution $(2 \mathrm{n}=4 \mathrm{x}=28)$ and 'common wheat' for hexaploid genotypes of the AABBDD genome constitution $(2 \mathrm{n}=6 \mathrm{x}=42)$. Cultivars of $T$. dicoccum and T. durum, both belonging to Emmer wheat, respectively are called emmer and durum wheat.

Designations of the wheat chromosomes used in this study follow the recommendations of the 7th International Wheat Genetics Symposium (Miller and Koebner, 1988). The former $4 \mathrm{~A}$ is renamed $4 \mathrm{~B}$, and the former $4 \mathrm{~B}$ renamed $4 \mathrm{~A}$.

\section{Breeding mutant stocks}

Striato-virescence. The abbreviation ' $\mathrm{sv}$ ' is used for this phenotype, and the basic symbol, $s v$, adopted for its genes. This abnormality is characterized by normal green seedling leaves in autumn, albinotic stripes on 
rosette leaves in winter (Fig. 1A, right), and recovery of normal leaf color in spring. When $s v$ homozygotes are grown in a greenhouse adjusted at $15^{\circ} \mathrm{C}$ or higher temperature, they do not express this abnormality.
Two tetraploid lines $(2 \mathrm{n}=28)$ homozygous for $N e 2$ genes were bred by transferring this gene from common wheat JF to the Emmer (Vernal) background. One line, named sv Ne2-4x, stably expressed the sv phenotype.
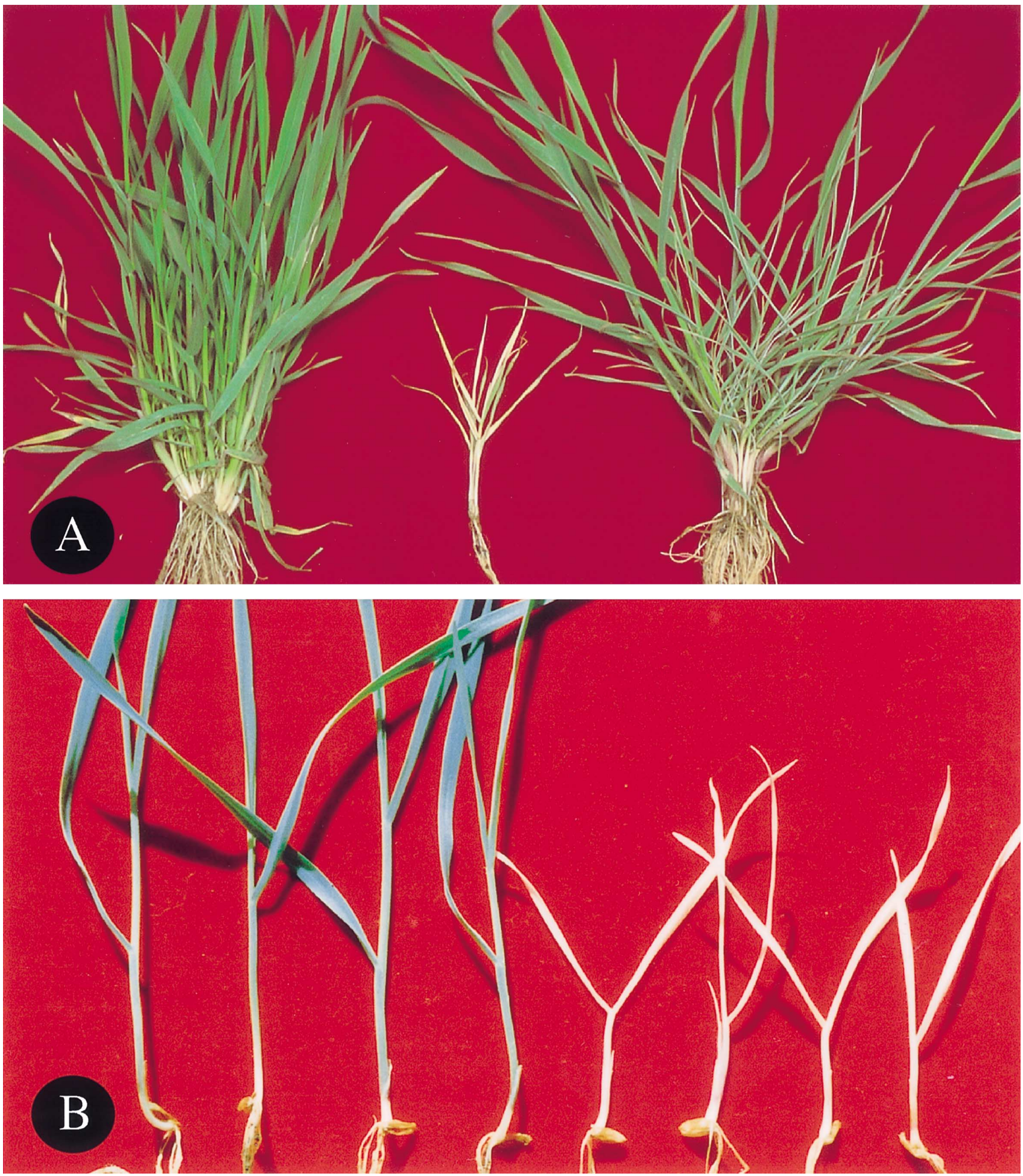

Fig. 1. (A): Rosette stage of a normal (left), delayed virescent (center), and striato- virescent plant (right). (B): Normal (four seedlings at left) and albinotic plants (four seedlings at right) segregated in an $\mathrm{F}_{4}$ progeny of the cross Ldn $\mathrm{x}($ Vernal $\mathrm{x} s v \mathrm{Ne2}-4 \mathrm{x}) \mathrm{F}_{1}$. 
Because Ldn carries $\mathrm{Ne} 1$ which causes hybrid necrosis in the presence of $\mathrm{Ne} 2$ (Tsunewaki, 1960), breeding an $\mathrm{Ne} 2$ free $s v$ homozygote was necessary to determine the chromosomal locations of $s v$ genes by means of aneuploid analysis with use of Ldn DS lines. This was done by selecting $s v$ homozygotes in the offspring of the cross, Ldn $\mathrm{x}$ (Vernal x $s v N e 2-4 \mathrm{x}) \mathrm{F}_{1}$, in which Vernal is free of both $N e 1$ and Ne2. The sv-homozygous line obtained that is free of $N e 2$ was named $s v n e 2-4 \mathrm{x}$.

Delayed virescence. The abbreviation for this phenotype is 'dv'. The basic symbol $d v$ is used for its genes. This phenotype is characterized by normal green-colored seedlings in autumn, which turn almost completely albino in winter (Fig. 1A, center). Most dv seedlings die at that stage, but a few survive through winter. Those that do gradually recover chlorophyll and growth vigor in the spring and finally set seeds. Their maturity, however, is about one month later than that of normal plants. When $d v$ homozygotes are grown in a greenhouse adjusted at $15^{\circ} \mathrm{C}$ or higher temperature, they do not show delayed virescence, although their growth vigor is subnormal. A few fixed $d v$ lines free of $N e 2$, obtained in the offspring of the cross Ldn x (Vernal x sv Ne2-4x) F $\mathrm{F}_{1}$, were used in the present analysis.

Albino. The abbreviation for this phenotype is 'abn'. The basic symbol $a b n$ is used for its genes. Albino seedlings lack chlorophyll from the time of germination (Fig. 1B), are pure white (or slightly purple when anthocyanin is present), and die at about the third leaf stage when the starch in the attached seeds is exhausted. Because albinos are completely lethal, no fixed albino lines were obtained. True-bred lines for each of the duplicated (or complementary) recessive $a b n$ genes therefore were selected from the offspring of the cross Ldn $\mathrm{x}$ (Vernal $\mathrm{x} s v$ Ne2-4x) $\mathrm{F}_{1}$, and used for abn gene identification. Details of the procedure for their breeding are given in the corresponding section in "RESULTS".

\section{Aneuploid analysis}

A complete set of the $14 \mathrm{Ldn}$ DS lines produced by Joppa and Williams (1988) was used. Each DS line is indicated by its D-genome chromosome, the replaced A- or B-genome homoeologue being given in parentheses. For example, Ldn $1 \mathrm{D}(1 \mathrm{~A})$ is a $\mathrm{DS}$ line in which a pair of $\mathrm{Ldn}$ $1 \mathrm{~A}$ chromosomes is replaced by a pair of CS 1D chromosomes. Of the $14 \mathrm{DS}$ lines, $4 \mathrm{D}(4 \mathrm{~A}), 5 \mathrm{D}(5 \mathrm{~A})$, and $6 \mathrm{D}(6 \mathrm{~B})$ respectively retained a single $4 \mathrm{~A}$ chromosome, single 5AL arm, and single 6BS arm.

In a preliminary study, the 14 DS lines and a normal Ldn line, the control, were crossed as female to (Vernal $\mathrm{x}$ $s v \mathrm{Ne} 2-4 \mathrm{x}) \mathrm{F}_{1}$ 's. For convenience, seeds obtained from these crosses are hereafter called $\mathrm{F}_{1}$ seeds. Open-pollinated $\mathrm{F}_{2}$ seeds were harvested from $30 \mathrm{~F}_{1}$ plants of each
DS line and $40 \mathrm{~F}_{1}$ 's of the control, but the $3 \mathrm{D}(3 \mathrm{~B})$ line gave only $11 \mathrm{~F}_{1}$ plants. The $\mathrm{F}_{2}$ seeds were sown in flats in a greenhouse, and the germination rate and frequency of albinos examined. All the green seedlings were transplanted to the field in late autumn. Segregation of $d v$ and sv plants was examined a few times during the winter.

In the advanced studies, the same set of DS lines and a normal Ldn line were crossed to $s v n e 2-4 \mathrm{x}$, to the $d v$ homozygote, and to the homozygote for each of the two complementary abn genes. $\mathrm{F}_{1}$ plants were grown in pots in a greenhouse, and $\mathrm{F}_{2}$ seeds obtained by self-pollination were sown in flats also in a greenhouse where segregation of albinos was observed. In early winter, the flats were taken outside. Segregation of $d v$ and sv plants in the individual $\mathrm{F}_{2}$ progenies was recorded a few times during the winter.

\section{RESULTS}

\section{Preliminary study}

As expected, the $\mathrm{F}_{1}$ populations of all the DS and control lines, except the Ldn 5D(5B) line, segregated normal and necrotic plants in about a $1: 1$ ratio. Line Ldn $5 \mathrm{D}$ (5B) lacks the 5B chromosomes of Ldn which carry Ne1. All the offspring therefore should be non-necrotic. In fact, 137 plants were normal, two others necrotic. The origins of these off-type plants are unknown. All the normal hybrids are assumed to be homozygous for ne2. All the parental lines in the advanced studies were descendants of those normal $\mathrm{F}_{1}$ 's.

All three chlorophyll abnormalities segregated (Table 1) in $F_{2}$ offspring of the normal $F_{1}$ 's. Several DS lines clearly showed segregation ratios for each chlorophyll abnormality that differed from those of the disomic population. It was, however, difficult to definitively determine which chromosomes carry the responsible genes. The reasons were (1) frequencies of all the abnormalities were low in the disomic (control) population, (2) co-segregation of all three abnormalities occurred, and interaction was suspected, (3) the $\mathrm{Ne} 2$ gene appeared to be linked to some chlorophyll abnormality genes. For a clear identification of the carrier chromosomes of the responsible genes, advanced studies therefore were made on fixed lines for each abnormality, which lines were free of the other abnormality genes.

\section{Advanced study of striato-virescence}

A fixed line for this abnormality, free of $\mathrm{Ne} 2$ and other chlorophyll abnormality genes, was crossed to Ldn DS lines and to a normal line (the control). $\mathrm{F}_{2}$ populations obtained by the self-pollination of $\mathrm{F}_{1}$ hybrids were examined for segregation of sv plants (Table 2). The frequency in most lines was close to $6.25 \%(=1 / 16)$, indicative that two duplicated recessive genes determine the expression of this phenotype. The postulated genes were assigned 
Table 1. Segregation of three chlorophyll abnormalities in the $\mathrm{F}_{2}$ generation of the crosses Ldn DS $\mathrm{x}($ Vernal $\mathrm{x} s v N e 2-4 \mathrm{x}) \mathrm{F}_{1}$.

\begin{tabular}{|c|c|c|c|c|c|c|c|c|c|c|}
\hline \multirow[t]{2}{*}{$\mathrm{F}_{2}$ line } & \multirow{2}{*}{$\begin{array}{c}\text { No. } \\
\text { progenies }\end{array}$} & \multirow{2}{*}{$\begin{array}{c}\text { No. seeds } \\
\text { sown }\end{array}$} & \multirow{2}{*}{$\begin{array}{c}\text { No. seeds } \\
\text { germinated }\end{array}$} & \multirow{2}{*}{$\begin{array}{c}\text { No. } \\
\text { albinos }\end{array}$} & \multirow{2}{*}{$\begin{array}{c}\% \\
\text { albinos }\end{array}$} & \multicolumn{3}{|c|}{ No. surviving plant } & \multirow{2}{*}{$\begin{array}{l}\% \\
\mathrm{sv}\end{array}$} & \multirow{2}{*}{$\begin{array}{l}\% \\
\mathrm{dv}\end{array}$} \\
\hline & & & & & & Total & sv & $\mathrm{dv}$ & & \\
\hline $1 \mathrm{D}(1 \mathrm{~A})$ & 30 & 1,200 & 1,171 & 30 & 2.56 & 1,127 & 18 & 7 & 1.60 & 0.62 \\
\hline $2 \mathrm{D}(2 \mathrm{~A})$ & 30 & 1,200 & 1,156 & 0 & $0.00 * *$ & 1,152 & 18 & 0 & 1.56 & 0.00 \\
\hline $3 \mathrm{D}(3 \mathrm{~A})$ & 30 & 1,200 & 1,144 & 26 & 2.27 & 1,096 & 68 & 4 & $6.20 * *$ & 0.36 \\
\hline $4 \mathrm{D}(4 \mathrm{~A})$ & 30 & 1,200 & 1,148 & 32 & 2.79 & 1,095 & 23 & 18 & 2.10 & $1.64^{* *}$ \\
\hline $5 \mathrm{D}(5 \mathrm{~A})$ & 30 & 1,200 & 1,119 & 6 & $0.54 * *$ & 1,092 & 29 & 0 & 2.66 & 0.00 \\
\hline $6 \mathrm{D}(6 \mathrm{~A})$ & 30 & 1,200 & 1,141 & 14 & $1.25^{*}$ & 1,106 & 38 & 13 & $3.44^{*}$ & $1.18^{*}$ \\
\hline $7 \mathrm{D}(7 \mathrm{~A})$ & 30 & 1,200 & 1,165 & 15 & $1.29 *$ & 1,111 & 21 & 12 & 1.89 & $1.08^{*}$ \\
\hline $1 \mathrm{D}(1 \mathrm{~B})$ & 30 & 1,200 & 1,136 & 27 & 2.38 & 1,100 & 14 & 6 & 1.27 & 0.55 \\
\hline $2 \mathrm{D}(2 \mathrm{~B})$ & 30 & 1,200 & 1,143 & 39 & 3.41 & 1,085 & 2 & 7 & $0.18^{* *}$ & 0.65 \\
\hline $3 \mathrm{D}(3 \mathrm{~B})$ & 11 & 1,032 & 940 & 13 & 1.38 & 897 & 9 & 7 & $1.00 *$ & 0.78 \\
\hline $4 \mathrm{D}(4 \mathrm{~B})$ & 30 & 1,200 & 1,150 & 30 & 2.61 & 1,093 & 38 & 6 & $3.48^{*}$ & 0.55 \\
\hline $5 \mathrm{D}(5 \mathrm{~B})$ & 30 & 1,200 & 1,135 & 9 & $0.79 * *$ & 1,106 & 27 & 15 & 2.44 & $1.36^{* *}$ \\
\hline $6 \mathrm{D}(6 \mathrm{~B})$ & 30 & 1,200 & 1,145 & 18 & 1.57 & 1,098 & 23 & 26 & 2.09 & $2.37^{* *}$ \\
\hline $7 \mathrm{D}(7 \mathrm{~B})$ & 30 & 1,200 & 1,156 & 10 & $0.87 * *$ & 1,128 & 12 & 10 & $1.06^{*}$ & 0.89 \\
\hline Disomic & 40 & 1,600 & 1,568 & 37 & 2.36 & 1,531 & 32 & 5 & 2.09 & 0.33 \\
\hline \multicolumn{11}{|l|}{ Total $^{1)}$} \\
\hline For sv & - & - & - & - & - & 13,484 & 284 & - & 2.11 & - \\
\hline For $d v$ & - & - & - & - & - & 14,580 & - & 129 & - & 0.88 \\
\hline For abn & - & 15,118 & 267 & - & 1.77 & - & - & - & - & - \\
\hline
\end{tabular}

1) Total excluding respective critical lines; $2 \mathrm{D}(2 \mathrm{~A}), 3 \mathrm{D}(3 \mathrm{~A})$, and $2 \mathrm{D}(2 \mathrm{~B})$ for sv, and $2 \mathrm{D}(2 \mathrm{~A})$ and $2 \mathrm{D}(2 \mathrm{~B})$ for both $\mathrm{dv}$ and abn $*$ and **: Significant respectively at the $5 \%$ and $1 \%$ levels of probability

Table 2. Frequency of striato-virescence (sv) in the $\mathrm{F}_{2}$ generation of the crosses Ldn DS's $\mathrm{x} s v$ ne2-4x.

\begin{tabular}{|c|c|c|c|c|c|c|c|c|}
\hline \multirow[t]{2}{*}{$\mathrm{F}_{2}$ line } & \multirow{2}{*}{$\begin{array}{c}\text { No. } \\
\text { progenies }\end{array}$} & \multicolumn{2}{|c|}{ No. of seeds } & \multicolumn{2}{|c|}{ No. of plants } & \multirow{2}{*}{$\begin{array}{l}\% \\
\mathrm{sv}\end{array}$} & \multirow{2}{*}{$\begin{array}{c}\chi^{2} \text {-value } \\
\text { (gr:sv=15:1) }\end{array}$} & \multirow{2}{*}{$\begin{array}{c}\chi^{2} \text {-value } \\
\text { (vs.disomic) }\end{array}$} \\
\hline & & Sown & Germinated & Green & Striato-v. & & & \\
\hline $1 \mathrm{D}(1 \mathrm{~A})$ & 4 & 200 & 200 & 186 & 14 & 7.00 & 0.19 & 3.64 \\
\hline $2 \mathrm{D}(2 \mathrm{~A})$ & 4 & 200 & 200 & 190 & 10 & 5.00 & 0.53 & 0.77 \\
\hline $3 \mathrm{D}(3 \mathrm{~A})$ & 4 & 200 & 197 & 177 & 20 & 10.15 & $5.12^{*}$ & $10.82^{* *}$ \\
\hline $4 \mathrm{D}(4 \mathrm{~A})$ & 4 & 200 & 200 & 187 & 13 & 6.50 & 0.02 & 2.76 \\
\hline $5 \mathrm{D}(5 \mathrm{~A})$ & 4 & 200 & 199 & 190 & 9 & 4.52 & 1.02 & 0.37 \\
\hline $6 \mathrm{D}(6 \mathrm{~A})$ & 4 & 200 & 199 & 185 & 14 & 7.04 & 0.21 & 3.69 \\
\hline $7 \mathrm{D}(7 \mathrm{~A})$ & 4 & 200 & 199 & 188 & 11 & 5.53 & 0.18 & 1.35 \\
\hline $1 \mathrm{D}(1 \mathrm{~B})$ & 4 & 200 & 200 & 192 & 8 & 4.00 & 1.73 & 0.09 \\
\hline $2 \mathrm{D}(2 \mathrm{~B})$ & 6 & 200 & 199 & 197 & 2 & 1.01 & $9.35^{* *}$ & 3.19 \\
\hline $3 \mathrm{D}(3 \mathrm{~B})$ & 4 & 200 & 186 & 174 & 12 & 6.45 & 0.01 & 2.58 \\
\hline $4 \mathrm{D}(4 \mathrm{~B})$ & 4 & 200 & 198 & 188 & 10 & 5.05 & 0.49 & 0.82 \\
\hline $5 \mathrm{D}(5 \mathrm{~B})$ & 4 & 200 & 200 & 190 & 10 & 5.00 & 0.53 & 0.77 \\
\hline $6 \mathrm{D}(6 \mathrm{~B})$ & 7 & 200 & 197 & 190 & 7 & 3.55 & 2.44 & 0.00 \\
\hline 7D(7B) & 4 & 200 & 200 & 192 & 8 & 4.00 & 1.73 & 0.09 \\
\hline Disomic & 4 & 400 & 399 & 385 & 14 & 3.51 & $5.12^{*}$ & - \\
\hline Pooled $^{1)}$ & 55 & 2,800 & 2,577 & 2,447 & 130 & 5.04 & $6.39 *$ & - \\
\hline
\end{tabular}

1) All progenies, except those of the $2 \mathrm{D}(2 \mathrm{~A}), 3 \mathrm{D}(3 \mathrm{~A})$, and $2 \mathrm{D}(2 \mathrm{~B})$ lines, are pooled.

$*$ and **: Significant respectively at the $5 \%$ and $1 \%$ levels of probability 
the symbols $s v 1$ and $s v 2$.

Disomic and pooled data indicated that the frequency of sv plants is slightly, but significantly lower than the expected $6.25 \%$. This deviation is not attributable to female sterility because female fertility of the disomic $\mathrm{F}_{1}$ 's was normal (average 94\%). One possible explanation is that there is a slight disadvantage (estimated to be about $5 \%$ ) in fertilization of pollen of the sv1sv2 genotype as compared to pollen having the $S v 1$ and/or $S v 2$ allele.

Based on the 15 green to $1 \mathrm{sv}$ ratio, a $\chi 2$-test was made (second column at right, Table 2). $\mathrm{F}_{2}$ progenies of two DS lines, $L d n 3 \mathrm{D}(3 \mathrm{~A})$ and $\operatorname{Ldn} 2 \mathrm{D}(2 \mathrm{~B})$, had ratios that deviated significantly from the expected value. In the Ldn $3 \mathrm{D}(3 \mathrm{~A})$ progenies, the frequency of sv plants was about two times the expected $6.25 \%$. The conclusion is that one of the duplicated genes, $s v 1$, is located on chromosome 3A of $s v$ ne2-4x. According to Joppa and Williams (1988, Table 5), about $41 \%$ of the $\mathrm{F}_{2}$ offspring of $3 \mathrm{~A} /$ $3 \mathrm{D}$ double monosomics have a pair of $3 \mathrm{~A}$ chromosomes. Therefore, about $10 \%$ (i. e., $41 \% \times 1 / 4$ ) of the $\mathrm{F}_{2}$ offspring of the cross, $\operatorname{Ldn} 3 \mathrm{D}(3 \mathrm{~A}) \mathrm{x} s v n e 2-4 \mathrm{x}$, are expected to have the sv phenotype, assuming that a double dose of $s v 1$, in addition to the homozygous condition of $s v 2$, is necessary for the sv phenotype. The actual frequency of $10.2 \%$ for offspring of $3 \mathrm{D}(3 \mathrm{~A})$ lines fits that frequency.

The extremely low frequency of sv plants in the $\mathrm{F}_{2}$ progenies of $L d n 2 \mathrm{D}(2 \mathrm{~B})$ suggests that chromosome $2 \mathrm{~B}$ or $2 \mathrm{D}$ carries an sv suppressor. The parental $\mathrm{F}_{1}$ 's, Ldn $2 \mathrm{D}(2 \mathrm{~B})$ $\mathrm{x} s v n e 2-4 \mathrm{x}$, differ from the control $\mathrm{F}_{1}$ 's in the following two respects. One is the presence of the $2 \mathrm{~B}$ chromosome in a single dose, as compared to the double dose in the control. The other is the presence of the $2 \mathrm{D}$ chromosome that is lacking in the control. Because the $2 \mathrm{~B}$ chromosome in the $\operatorname{Ldn} 2 \mathrm{D}(2 \mathrm{~B}) \mathrm{x} s v$ ne2-4x $\mathrm{F}_{1}$ 's was derived from the $s v$ ne2-4x parent, it can not be the carrier of the $\mathrm{sv}$ suppressor. Therefore, chromosome 2D must carry the suppressor. According to the findings of Joppa and Williams (cited above), the frequency of 2D-chromosome carriers in the $\mathrm{F}_{2}$ offspring of $2 \mathrm{~B} / 2 \mathrm{D}$ double monosomics is about $34 \%$, close to $1 / 3$. The frequency of sv plants in the $\mathrm{F}_{2}$ 's of the cross $\mathrm{Ldn} 2 \mathrm{D}(2 \mathrm{~B}) \mathrm{x}$ sv ne2-4x therefore is expected to be about $1 / 4 \times 1 / 4 \times 1 / 3$ (ca. $2.1 \%$ ). The observed frequency of $1.0 \%$ fits the expected ratio $(\chi 2=$ $0.670, \mathrm{df}=1$ ).

Based on the above deduction, $F_{2}$ progenies of the cross Ldn $2 \mathrm{D}(2 \mathrm{~A}) \mathrm{x} s v n e 2-4 \mathrm{x}$ should segregate sv plants at a much lower frequency than do disomic $\mathrm{F}_{2}$ 's and should show an sv plant frequency similar to that of the cross Ldn $2 \mathrm{D}(2 \mathrm{~B}) \mathrm{x} s v n e 2-4 \mathrm{x}$ because they have the $2 \mathrm{D}$ chromosome in common. This, however, was not the case. They segregated sv plants at a frequency similar to that of the disomic $\mathrm{F}_{2}$ 's, indicative that chromosome $2 \mathrm{~A}$ of $s v$ $n e 2-4 \mathrm{x}$ carries the $s v 2$ gene; the other striato-virescence gene. According to Joppa and Williams (cited above), the frequency of $\mathrm{F}_{2}$ plants that have a double dose of the $2 \mathrm{~A}$ chromosome (accordingly, a double dose of the $s v 2$ gene) but which lack the $2 \mathrm{D}$ chromosome (therefore being free of the sv suppressor) is about 35\%. The frequency of sv plants in $\mathrm{F}_{2}$ progenies of the cross $\operatorname{Ldn} 2 \mathrm{D}(2 \mathrm{~A}) \mathrm{x} s v$ ne2$4 \mathrm{x}$ therefore is expected to be about $0.35 \times 1 / 4$, about $8.7 \%$. This fits the observed frequency of $5.0 \%(\chi 2=$ $3.522, \mathrm{df}=1$ ).

The sv suppressor is assumed to be a wild-type homoeoallele of the $s v 2$ gene as they are located on the $2 \mathrm{D}$ and $2 \mathrm{~A}$ chromosomes respectively in the same homoeologous group. This suppressor therefore is designated Sv3. The fact that the frequency of sv plants in the preliminary study (2.1\%, ref. Table 1$)$ was about half that in the present study (5.0\%) is explained by the genotypic difference of the male parents crossed to Ldn DS lines; $S v 1 s v 1$ sv2sv2 in the preliminary study (ref. Table 1) and $s v 1 s v 1 s v 2 s v 2$ in this one.

\section{Advanced study of delayed virescence}

Fixed lines with delayed virescence, free of $\mathrm{Ne} 2$ and other chlorophyll abnormality genes, were crossed to Ldn DS lines, and the $\mathrm{F}_{1}$ hybrids self-pollinated. $\mathrm{F}_{2}$ offspring were tested for the segregation of dv plants (Table 3).

The frequency of dv plants was close to $25 \%$ in about $1 /$ 3 of the DS lines, but all the lines had frequencies lower than $25 \%$. Control $\mathrm{F}_{1}$ 's were fully fertile on the female side ( $97 \%$ selfed seed fertility), but the $\mathrm{F}_{2}$ progenies had frequencies of dv plants lower than 25\%. This indicates that there is a fertilization disadvantage in having $d v$ carrying pollen as opposed to having $D v$-carrying pollen (the estimated disadvantage is ca. 14\%). According to the $\mathrm{F}_{2}$ segregation ratio, the $\operatorname{Ldn}$ and $d v$ homozygotes appear to differ by a single gene pair.

Segregation ratios of dv plants in $\mathrm{F}_{2}$ progenies of the DS lines were tested against the control $\mathrm{F}_{2}$ (disomic) ratio because the frequency of dv plants in the controls statistically was lower than $25 \% . \quad \mathrm{F}_{2}$ progenies of two DS lines, $\mathrm{Ldn} 2 \mathrm{D}(2 \mathrm{~A})$ and $\mathrm{Ldn} 7 \mathrm{D}(7 \mathrm{~A})$, had ratios that deviated significantly from the disomic ratio; lower in the former, higher in the latter. $\operatorname{Ldn} 2 \mathrm{D}(2 \mathrm{~B})$ progenies did not differ from the disomic ones. These findings suggest that the 2D chromosome carries a suppressor for $\mathrm{dv}$ expression and that the $2 \mathrm{~B}$ chromosome has a $d v$ gene. If not, the $\mathrm{F}_{2}$ progenies of $\mathrm{Ldn} 2 \mathrm{D}(2 \mathrm{~B})$ would segregate $\mathrm{dv}$ plants at a low frequency similar to that of $\mathrm{Ldn}$ $2 \mathrm{D}(2 \mathrm{~A})$. The $\mathrm{dv}$ frequency in $\mathrm{F}_{2}$ progenies of $\mathrm{Ldn} 7 \mathrm{D}(7 \mathrm{~A})$ was $22.1 \%$, only a little lower than $25 \%$, indicative that chromosome 7A has no relation to the dv phenotype.

Two conclusions are drawn: (1) delayed virescence is controlled by a single gene, $d v 1$, located on chromosome $2 \mathrm{~B}$ of the $d v$ homozygote (consequently, the $2 \mathrm{~B}$ of Ldn has its wild-type allele, $D v 1$ ); (2) chromosome $2 \mathrm{D}$ of CS carries a $d v$ locus on which a wild-type homoeoallele of $d v 1$ is located. This wild-type homoeoallele is designated $D v 3$ because of its presence in the third wheat genome, D. 
Table 3. Segregation of delayed virescence $(\mathrm{dv})$ in the $\mathrm{F}_{2}$ generation of the crosses Ldn DS's $\mathrm{x} d v$ homozygote.

\begin{tabular}{|c|c|c|c|c|c|c|c|c|}
\hline \multirow[t]{2}{*}{$\mathrm{F}_{2}$ line } & \multirow{2}{*}{$\begin{array}{c}\text { No. } \\
\text { progenies }\end{array}$} & \multicolumn{2}{|c|}{ No. of seeds } & \multicolumn{2}{|c|}{ No. of plants } & \multirow{2}{*}{$\begin{array}{l}\% \\
\mathrm{dv}\end{array}$} & \multirow{2}{*}{$\begin{array}{c}\chi^{2} \text {-value } \\
\text { (vs. disomic) }\end{array}$} & \multirow{2}{*}{$\begin{array}{l}\chi 2 \text {-value } \\
\text { (gr: } \mathrm{dv}=3: 1\end{array}$} \\
\hline & & Sown & Germinated & Green & $\mathrm{dv}$ & & & \\
\hline $1 \mathrm{D}(1 \mathrm{~A})$ & 4 & 200 & 200 & 163 & 37 & 18.5 & 0.87 & $4.51^{*}$ \\
\hline $2 \mathrm{D}(2 \mathrm{~A})$ & 4 & 200 & 200 & 183 & 17 & 8.5 & $5.44 *$ & $29.04^{* *}$ \\
\hline $3 \mathrm{D}(3 \mathrm{~A})$ & 4 & 200 & 200 & 166 & 34 & 17.0 & 0.23 & $6.83^{* *}$ \\
\hline $4 \mathrm{D}(4 \mathrm{~A})$ & 4 & 200 & 200 & 176 & 24 & 12.0 & 1.23 & $18.03^{* *}$ \\
\hline $5 \mathrm{D}(5 \mathrm{~A})$ & 4 & 200 & 200 & 166 & 34 & 17.0 & 0.23 & $6.83^{* *}$ \\
\hline $6 \mathrm{D}(6 \mathrm{~A})$ & 4 & 200 & 200 & 170 & 30 & 15.0 & 0.02 & $10.67 * *$ \\
\hline $7 \mathrm{D}(7 \mathrm{~A})$ & 4 & 240 & 240 & 187 & 53 & 22.1 & $4.24^{*}$ & 1.09 \\
\hline $1 \mathrm{D}(1 \mathrm{~B})$ & 4 & 200 & 200 & 163 & 37 & 18.5 & 0.87 & $4.51^{*}$ \\
\hline $2 \mathrm{D}(2 \mathrm{~B})$ & 4 & 200 & 200 & 158 & 42 & 21.0 & 2.74 & 1.71 \\
\hline $3 \mathrm{D}(3 \mathrm{~B})$ & 4 & 200 & 200 & 156 & 44 & 22.0 & 3.75 & 0.96 \\
\hline $4 \mathrm{D}(4 \mathrm{~B})$ & 4 & 200 & 200 & 156 & 44 & 22.0 & 3.75 & 0.96 \\
\hline $5 \mathrm{D}(5 \mathrm{~B})$ & 4 & 200 & 200 & 159 & 41 & 20.5 & 2.29 & 2.16 \\
\hline $6 \mathrm{D}(6 \mathrm{~B})$ & 6 & 113 & 113 & 89 & 24 & 21.2 & 2.06 & 0.85 \\
\hline $7 \mathrm{D}(7 \mathrm{~B})$ & 4 & 200 & 200 & 167 & 33 & 16.5 & 0.11 & $7.71^{* *}$ \\
\hline Disomic & 7 & 350 & 350 & 296 & 54 & 15.4 & - & - \\
\hline Pooled $^{1)}$ & - & 2,703 & 2,703 & 2,214 & 489 & 18.1 & - & $68.81^{* *}$ \\
\hline
\end{tabular}

1) All pooled except the $2 \mathrm{D}(2 \mathrm{~A})$ and $2 \mathrm{D}(2 \mathrm{~B})$ lines

* and **: Significant respectively at the 5\% and $1 \%$ levels of probability

Based on these assumptions, the respective frequencies of $\mathrm{dv}$ plants in the $\mathrm{F}_{2}$ progenies of the two critical DS lines $\operatorname{Ldn} 2 \mathrm{D}(2 \mathrm{~A})$ and $\operatorname{Ldn} 2 \mathrm{D}(2 \mathrm{~B})$ should be $6.2 \%$ and $25.7 \%$, close to their observed frequencies of $8.5 \%$ and $21.0 \%$.

As stated hereafter (ref. Table 6), the $\mathrm{F}_{2}$ population of the cross Vernal x Ldn produced some dv plants, indicative that each parent has one or the other duplicated recessive $d v$ gene. Consistent with the previous conclusions, the genotype of Ldn must be $D v 1 D v 1 d v 2 d v 2$ and that of Vernal $d v 1 d v 1 D v 2 D v 2$. Although the carrier chromosome of the $d v 2$ locus was not determined in this study, that locus is assumed to be on the $2 \mathrm{~A}$ chromosome based on the homoeology of the $2 \mathrm{~A}$ chromosome to both the $2 \mathrm{~B}$ and $2 \mathrm{D}$ chromosomes, carriers of the $d v 1$ and $d v 3$ loci, respectively. The $d v$ homozygote should have the dv2 allele in common with Ldn because they showed a single gene difference, $d v 1 \mathrm{vs} D v 1$.

\section{Advanced study of albino}

Breeding homozygous lines for each of the two duplicated $\boldsymbol{a b n}$ genes. The preliminary study showed that $\mathrm{F}_{2}$ progenies of the cross Ldn $\mathrm{x}$ (Vernal $\mathrm{x} s v \mathrm{Ne} 2-4 \mathrm{x}$ ) $\mathrm{F}_{1}$ segregated some albinos together with other chlorophyll abnormalities (Table 1). About ten green $\mathrm{F}_{2}$ plants (being the ne2ne2 homozygotes, free of $\mathrm{Ne2}$ ) were selected from these progenies, and self-pollinated. Their $\mathrm{F}_{3}$ generations were tested for segregation of albinos. $F_{3}$ progenies derived from four $\mathrm{F}_{2}$ plants segregated albinos. A few green sibs were self-pollinated in each of the four $\mathrm{F}_{2}$ families. $\mathrm{F}_{4}$ progenies also were tested for ablino segre- gation. Three to five $\mathrm{F}_{4}$ progenies that segregated green and albino plants at nearly a 3:1 ratio were selected from each $\mathrm{F}_{2}$ family. Five green sibs were selected in each $\mathrm{F}_{4}$ progeny, and subsequent progenies $\left(\mathrm{F}_{5}\right.$ generation) again tested for albino segregation. Totally, $74 \mathrm{~F}_{5}$ progenies were tested, of which 32 were fixed for the green phenotype and assumed to be homozygous for one of the duplicated albino genes. Of those progenies, 20 were used in the following allelism test of abn genes.

Allelism test of albino genes. Each of the 20 test lines and a normal Ldn line were crossed to at least two other test lines. The $\mathrm{F}_{1}$ hybrids (in Table 4, hybrids between $\mathrm{F}_{6}$ lines) were self-pollinated, and their $\mathrm{F}_{2}$ progenies tested for segregation of albino plants. Table 4 shows that neither the $\mathrm{F}_{2}$ 's of crosses between lines of the No. 1 to $3 \mathrm{~F}_{2}$ families (Group I cross combinations in the Table) nor those between lines of the No. 4 family (Group II combinations) segregated any albino plants, whereas $\mathrm{F}_{2}$ 's between lines of the No. 1 to 3 families and those of the No. 4 family (Group III combinations) all segregated some albino plants. These findings indicate that lines of the No. 1 to $3 \mathrm{~F}_{2}$ families carry one of the duplicated albino genes (abn1), whereas those of the No. 4 family carry the other one (abn2). Ldn should have abn1.

Aneuploid analysis of albino genes. Because Ldn is a carrier of the $a b n 1$ gene, the $a b n 2$ gene alone was subjected to aneuploid analysis, for which a few lines of the abn2 homozygote (Group II lines in Table 4) were crossed 
Table 4. Segregation of albinos in self-pollinated progenies of hybrids between $\mathrm{F}_{6}$ lines derived from the cross Ldn $\mathrm{x}$ (Vernal $\mathrm{x}$ sv Ne2-4x) $\mathrm{F}_{1}$.

\begin{tabular}{|c|c|c|c|c|c|c|c|c|c|}
\hline \multirow{2}{*}{$\begin{array}{l}\text { Cross } \\
\text { combination }\end{array}$} & \multicolumn{3}{|c|}{ No. of plants } & \multirow{2}{*}{$\begin{array}{c}\% \\
\text { albino }\end{array}$} & \multirow{2}{*}{$\begin{array}{l}\text { Cross } \\
\text { combination }\end{array}$} & \multicolumn{3}{|c|}{ No. of plants } & \multirow{2}{*}{$\begin{array}{c}\% \\
\text { albinc }\end{array}$} \\
\hline & Total & Normal & Albino & & & Total & Normal & Albino & \\
\hline Group I & & & & & Group II & & & & \\
\hline $\operatorname{Ldn}(-) \times 165(1)$ & 400 & 400 & 0 & 0.0 & $183(4) \times 184(4)$ & 400 & 400 & 0 & 0.0 \\
\hline $161(1) \times 165(1)$ & 381 & 381 & 0 & 0.0 & $184(4) \times 235$ & 394 & 394 & 0 & 0.0 \\
\hline $157(1) \times 161(1)$ & 385 & 385 & 0 & 0.0 & $191(4) \times 242(4)$ & 400 & 400 & 0 & 0.0 \\
\hline $157(1) \times 200(3)$ & 397 & 397 & 0 & 0.0 & & & & & \\
\hline $165(1) \times 200(3)$ & 399 & 399 & 0 & 0.0 & Group III & & & & \\
\hline $158(1) \times 208(3)$ & 396 & 396 & 0 & 0.0 & $\operatorname{Ldn}(-) \times 191(4)$ & 398 & 382 & 16 & 4.0 \\
\hline $208(3) \times 179(2)$ & 398 & 398 & 0 & 0.0 & $274(3) \times 191(4)$ & 397 & 382 & 15 & 3.8 \\
\hline $179(2) \times 176(2)$ & 397 & 397 & 0 & 0.0 & $274(3) \times 242(4)$ & 392 & 362 & 30 & 7.7 \\
\hline $176(2) \times 167(2)$ & 399 & 399 & 0 & 0.0 & $151(1) \times 183(4)$ & 395 & 382 & 13 & 3.3 \\
\hline $167(2) \times 171(2)$ & 401 & 401 & 0 & 0.0 & $151(1) \times 235$ & 396 & 388 & 8 & 2.0 \\
\hline $171(2) \times 170(2)$ & 398 & 398 & 0 & 0.0 & & & & & \\
\hline $170(2) \times 176(2)$ & 400 & 400 & 0 & 0.0 & & & & & \\
\hline $158(1) \times 197(3)$ & 401 & 401 & 0 & 0.0 & & & & & \\
\hline $197(3) \times 253(3)$ & 400 & 400 & 0 & 0.0 & & & & & \\
\hline $253(3) \times 274(3)$ & 400 & 400 & 0 & 0.0 & & & & & \\
\hline
\end{tabular}

Note: Numbers in parentheses indicate $\mathrm{F}_{2}$ families.

to Ldn DS lines and to a normal Ldn line as the control. The $\mathrm{F}_{1}$ hybrids were self-pollinated, and the $\mathrm{F}_{2}$ progenies tested for abn plant segregation.

Table 5 shows that the overall frequency of abn plants was lower than the $6.25 \%$ expected based on two recessive gene segregations. Again, the disadvantage for fertilization of having abn-carrying pollen as compared to Abncarrying pollen is indicated. Because the female fertility of the disomic $\mathrm{F}_{1}$ 's was normal (ca. 98\% after self pollination), the disadvantage for fertilization of having abn1abn2-pollen is estimated to be ca. $15 \%$.

To identify which chromosomes carry the $a b n$ loci, abn frequencies in $\mathrm{F}_{2}$ 's of the DS lines were compared to the disomic ratio. Only a single line, $\mathrm{DS} 2 \mathrm{D}(2 \mathrm{~A})$, which segregated no albino, deviated significantly from the disomic ratio. This is explained by the hypothesis that chromosome $2 \mathrm{~A}$ of Ldn carries the abn1 gene and that the 2D chromosome of CS carries its suppressor. Owing to the homoeology of chromosomes $2 \mathrm{~A}$ and $2 \mathrm{D}$, this suppressor was named $A b n 3$ for its presence in the third wheat genome.

The presence of the Abn3 gene on chromosome 2D should reduce the frequency of abn plants in the $\mathrm{F}_{2}$ population of the cross DS $2 \mathrm{D}(2 \mathrm{~B}) \mathrm{x}$ abn2 homozygote as compared to the disomic frequency, but it did not (ref. Table 5 ), indicative that chromosome $2 \mathrm{~B}$ of the abn2 homozygote carries $a b n 2$, the other albino gene. Therefore, $2.2 \%$ of the above $\mathrm{F}_{2}$ 's would be expected to be albino, assuming that the respective frequencies of the $2 \mathrm{D}$-free female and male $F_{1}$ gametes are $19.7 \%$ and $62.5 \%$ (after Joppa and Williams, 1988) and that there is a $15 \%$ disadvantage for participation in fertilization in having abn1abn2-pollen as compared to having wild type pollen. The observed frequency of $3.3 \%$ fits this expected frequency $(\chi 2=2.81$, $\mathrm{df}=1$ ). Two conclusions therefore were drawn: (1) $a b n 1$ and $a b n 2$ respectively are located on chromosomes $2 \mathrm{~A}$ and 2B, and (2) chromosome 2D of CS carries Abn3, the wildtype homoeoallele.

Gene origins of the three chlorophyll abnormalities

The sv trait first was found in six-times self-pollinated offspring of the $\mathrm{SB}_{2}$ hybrids, JF x Vernal ${ }^{3}$, in which Vernal was the recurrent pollen parent. Of the $\mathrm{SB}_{2}$ hybrids, those having the normal chromosome complements of Emmer wheat were selected cytologically and used for further self-pollination. Because $s v \mathrm{Ne2}-4 \mathrm{x}$ has both the $s v 1$ and $s v 2$ genes and Vernal shows a single gene difference, the undoubted origin of either sv1 or sv2 is Vernal, and therefore the other gene must be derived from JF. It is not clear, however, which gene is from Vernal and which from JF.

As for the origin of $d v$ genes, the $\mathrm{F}_{2}$ generation of the cross, Vernal x Ldn, segregated some dv plants (ref. Table 6 ), indicative that the dv trait is controlled by two recessive genes and that Vernal carries one and Ldn the other. The $d v$ homozygote is the double recessive for those genes. One of them, $d v 1$, is located on chromosome $2 \mathrm{~B}$ of the $d v$ homozygote, and Ldn carries the dominant 
Table 5. Albino frequencies in the $\mathrm{F}_{2}$ progenies of the crosses Ldn DS's $\mathrm{x}$ abn2 homozygote.

\begin{tabular}{|c|c|c|c|c|c|c|c|}
\hline $\mathrm{F}_{2}$ line & $\begin{array}{c}\text { No. } \\
\text { progenies }\end{array}$ & $\begin{array}{l}\text { No. seeds } \\
\text { sown }\end{array}$ & $\begin{array}{l}\text { No. seeds } \\
\text { germinated }\end{array}$ & $\begin{array}{c}\% \\
\text { germination }\end{array}$ & $\begin{array}{c}\text { No. } \\
\text { albinos }\end{array}$ & $\begin{array}{c}\% \\
\text { albinos }\end{array}$ & $\begin{array}{c}\chi^{2-} \\
\text { value }^{1)}\end{array}$ \\
\hline $1 \mathrm{D}(1 \mathrm{~A})$ & 6 & 600 & 588 & 98.0 & 16 & 2.72 & 0.67 \\
\hline $2 \mathrm{D}(2 \mathrm{~A})$ & 6 & 600 & 593 & 98.8 & 0 & 0.00 & $12.63 * *$ \\
\hline $3 \mathrm{D}(3 \mathrm{~A})$ & 6 & 598 & 578 & 96.7 & 7 & 1.21 & 1.73 \\
\hline $4 \mathrm{D}(4 \mathrm{~A})$ & 6 & 600 & 595 & 99.2 & 14 & 2.35 & 0.12 \\
\hline $5 \mathrm{D}(5 \mathrm{~A})$ & 5 & 600 & 583 & 97.2 & 14 & 2.40 & 0.17 \\
\hline $6 \mathrm{D}(6 \mathrm{~A})$ & 6 & 600 & 591 & 98.5 & 15 & 2.54 & 0.35 \\
\hline $7 \mathrm{D}(7 \mathrm{~A})$ & 6 & 600 & 582 & 97.0 & 10 & 1.72 & 0.30 \\
\hline $1 \mathrm{D}(1 \mathrm{~B})$ & 6 & 449 & 440 & 98.0 & 15 & 3.41 & 2.29 \\
\hline $2 \mathrm{D}(2 \mathrm{~B})$ & 6 & 510 & 489 & 95.9 & 16 & 3.27 & 2.00 \\
\hline $3 \mathrm{D}(3 \mathrm{~B})$ & 7 & 600 & 586 & 97.7 & 7 & 1.19 & 1.82 \\
\hline $4 \mathrm{D}(4 \mathrm{~B})$ & 6 & 600 & 596 & 99.3 & 19 & 3.19 & 1.96 \\
\hline $5 \mathrm{D}(5 \mathrm{~B})$ & 6 & 600 & 579 & 96.5 & 8 & 1.38 & 1.10 \\
\hline $6 \mathrm{D}(6 \mathrm{~B})$ & 6 & 146 & 143 & 97.9 & 3 & 2.10 & 0.00 \\
\hline $7 \mathrm{D}(7 \mathrm{~B})$ & 6 & 600 & 581 & 96.8 & 13 & 2.24 & 0.03 \\
\hline Disomic & 6 & 1,200 & 1,190 & 99.2 & 25 & 2.10 & - \\
\hline $\operatorname{Ldn}$ & 5 & 600 & 600 & 100.0 & 0 & 0.00 & $12.78 * *$ \\
\hline abn2 homo. & 6 & 600 & 599 & 99.8 & 0 & 0.00 & $12.76 * *$ \\
\hline Total $^{2)}$ & - & 8,303 & 8,121 & 97.8 & 182 & 2.24 & - \\
\hline
\end{tabular}

1) Tested against the disomic $F_{2}$ ratio

2) Total $\mathrm{F}_{2}$ 's except the $2 \mathrm{D}(2 \mathrm{~A})$ and $2 \mathrm{D}(2 \mathrm{~B})$ lines

**: Significant at the $1 \%$ level of probability

Table 6. Segregation of three chlorophyll abnormalities in the $\mathrm{F}_{2}$ generations of the parental stocks.

\begin{tabular}{|c|c|c|c|c|c|c|c|c|c|}
\hline \multirow[t]{2}{*}{ Material } & \multicolumn{4}{|c|}{ Greenhouse } & \multicolumn{5}{|c|}{ Field } \\
\hline & $\begin{array}{l}\text { No. seeds } \\
\text { sown }\end{array}$ & $\begin{array}{c}\text { No. } \\
\text { germ. }\end{array}$ & $\begin{array}{c}\text { No. } \\
\text { albinos }\end{array}$ & $\begin{array}{c}\% \\
\text { albinos }\end{array}$ & $\begin{array}{l}\text { Total } \\
\text { grown }\end{array}$ & $\begin{array}{l}\text { No. } \\
\text { sv }\end{array}$ & $\begin{array}{l}\text { No. } \\
\text { dv }\end{array}$ & $\begin{array}{l}\% \\
\mathrm{sv}\end{array}$ & $\begin{array}{l}\% \\
\mathrm{dv}\end{array}$ \\
\hline Vernal x Ldn $\mathrm{F}_{2}$ & 600 & 513 & 7 & 1.4 & 516 & 0 & 5 & 0.0 & 1.0 \\
\hline Vernal x sv Ne2-4x $\mathrm{F}_{2}$ & 320 & 291 & 0 & 0.0 & 290 & 63 & 0 & 21.7 & 0.0 \\
\hline sv Ne2-4x x Vernal $\mathrm{F}_{2}$ & 300 & 262 & 0 & 0.0 & 263 & 56 & 0 & 21.3 & 0.0 \\
\hline Ldn (control) & 430 & 421 & 0 & 0.0 & 421 & 0 & 0 & 0.0 & 0.0 \\
\hline sv Ne2-4x (control) & 30 & 24 & 0 & 0.0 & 24 & 24 & 0 & 100.0 & 0.0 \\
\hline
\end{tabular}

Note: The observed ratio of 553 normal : $119 \mathrm{sv}$ in the (Vernal xx $s v N e 2-4 \mathrm{x}$ ) $\mathrm{F}_{2}$ 's fits a $3: 1$ ratio.

allele $D v 1$ on the same chromosome. Clearly, the $d v 1$ and $d v 2$ of the $d v$ homozygote originated respectively from Vernal and Ldn.

The $\mathrm{F}_{2}$ generation of the same cross, Vernal $\mathrm{x}$ Ldn, also segregated some albino plants. Because Ldn carries the abn1 gene (ref. Table 4), Vernal must carry the other albino gene, $a b n 2$. The respective origins of $a b n 1$ and $a b n 2$ therefore are Ldn and Vernal.

\section{DISCUSSION}

Overall genetic systems for chlorophyll abnormalities. Loci and alleles identified for the three chlorophyll abnormalities of striato-virescence, delayed virescence, and albino are summarized in Table 7.

Frankel (1950) reported triplicated recessive genes for striato-virescence in common wheat. The present studies indicate the presence of two loci, sv1 and $s v 2$, in Emmer wheat, and a third sv3 locus in the D genome of common wheat in agreement with his findings. Nishikawa (1986) reported strong association of the albino phenotype with a $2 \mathrm{~B}$ telosome in various hybrid populations derived from $\mathrm{F}_{1}$ 's between Vernal and $2 \mathrm{~B}$ double ditelocentrics of the durum wheat 'LD222'. This suggests that the $a b n 1$ gene is present on chromosome $2 \mathrm{~B}$ of LD222 as in Ldn and of $a b n 2$ in Vernal, which supports 
Table 7. Genotypes determined by aneuploid analyses of parental and derivative strains of the three chlorophyll abnormalities.

\begin{tabular}{|c|c|c|c|c|c|c|c|c|c|c|}
\hline \multirow{4}{*}{ Strain } & \multirow{4}{*}{ Phenotype } & \multicolumn{9}{|c|}{ Character / chromosome / locus } \\
\hline & & \multicolumn{3}{|c|}{ Striato-virescence } & \multicolumn{3}{|c|}{ Delayed virescence } & \multicolumn{3}{|c|}{ Albino } \\
\hline & & $3 \mathrm{~A}$ & $2 \mathrm{~A}$ & $2 \mathrm{D}$ & $2 \mathrm{~A}(?)$ & $2 \mathrm{~B}$ & $2 \mathrm{D}$ & $2 \mathrm{~A}$ & $2 \mathrm{~B}$ & $2 \mathrm{D}$ \\
\hline & & sv1 & sv2 & sv3 & $d v 2$ & $d v 1$ & $d v 3$ & $a b n 1$ & $a b n 2$ & $a b n 3$ \\
\hline Langdon & normal & $S v 1$ & Sv2 & - & $d v 2$ & $D v 1$ & - & $a b n 1$ & $A b n 2$ & - \\
\hline Vernal $^{1)}$ & normal & Sv1 & $s v 2$ & - & $D v 2$ & $d v 1$ & - & $A b n 1$ & $a b n 2$ & - \\
\hline sv Ne2-4x & sv & $s v 1$ & sv2 & - & $D v 2$ & $d v 1$ & - & $A b n 1$ & $a b n 2$ & - \\
\hline$s v$ homozygote & sv & $s v 1$ & $s v 2$ & - & $?$ & $D v 1$ & - & $?$ & Abn2 & - \\
\hline$d v$ homozygote & $\mathrm{dv}$ & $?$ & $S v 2$ & - & $d v 2$ & $d v 1$ & - & $?$ & $A b n 2$ & - \\
\hline$a b n 1$ homozygote & normal & $S v 1$ & $S v 2$ & - & $?$ & $D v 1$ & - & $a b n 1$ & Abn2 & - \\
\hline abn2 homozygote & normal & $S v 1$ & $S v 2$ & - & $?$ & $D v 1$ & - & $A b n 1$ & $a b n 2$ & - \\
\hline Chinese Spring & normal & - & - & Sv3 & - & - & Dv3 & - & - & Abn3 \\
\hline
\end{tabular}

-: No locus, ?: Not identified

1) Alternative gene assignments for Vernal: $s v 1$ gene on chromosome $3 \mathrm{~A}$ and $\mathrm{Sv} 2$ gene on chromosome $2 \mathrm{~A}$

the present findings.

Except for $s v 1$, all the loci are located on group 2 homoeologous chromosomes. Chromosome $2 \mathrm{~A}$ bears the $s v 2, d v 2$ (possibly), and abn1 loci. Of the three mutants, the $s v 2$ allele is linked to neither $d v 2$ nor $a b n 1$. The last two genes may be linked, but recombination takes place between them because both delayed virescent and albinotic plants were segregated among normal plants in selfpollinated offspring of a single hybrid plant (ref. Table 1). All three mutant genes therefore must have separate loci. Similarly, chromosome $2 \mathrm{~B}$ carries the $d v 1$ and $a b n 2$ loci. Again, recombination takes place, providing evidence that their loci differ (Tables 1 and 7).

Two other types of chlorophyll abnormalities, virescence and chlorina, have been reported in common wheat (ref. McIntosh et al., 1998). Virescence is controlled by two loci; $v 1$ on chromosome 3B (Neatby's virescence) and $v 2$ on chromosome $3 \mathrm{~A}$ (Hermsen's virescence). Chlorina is controlled by three homoeoloci; $c n-A 1, c n-B 1$ and $c n-D 1$ on group 7 chromosomes. Here, except for the $s v 1$ locus on chromosome $3 \mathrm{~A}$, all the $s v, d v$ and $a b n$ loci located on group 2 chromosomes are independent of the $v$ and $c n$ loci. Virescence, chlorina, striato-virescence, delayed virescence, and albino therefore all have different genetic bases, but whether there is a relationship between $v 2$ and $s v 1$, both on chromosome $3 \mathrm{~A}$, is not known.

Use of the duplicated recessive genes in phylogenetic studies of Emmer wheat. Complementary genes, such as the Ne1 and Ne2 for hybrid necrosis, Ch1 and Ch2 for Type 1 hybrid chlorosis, and $C s 1$ and $C s 2$ for Type 2 hybrid chlorosis (Hermsen, 1963; Tsunewaki and Nakai, 1973), have proved useful in studies of phylogenetic differentiation in polyploid wheats. This type of system is extremely efficient because the genotype of the individual being tested can be determined immediately from phenotypes of the $F_{1}$ hybrids between the testers and that individual. Unfortunately, in polyploid wheats the known complementary gene systems are few.

In Emmer wheat, the duplicated recessive genes for chlorophyll abnormalities reported here can be used. For example, Ldn and Vernal can be used as respective testers for the delayed virescence genes $d v 1$ and $d v 2$. If a cultivar carries $d v 1$ or $d v 2$, its $\mathrm{F}_{2}$ progeny from a cross to Ldn or Vernal will segregate some delayed virescent plants. For albino, the same tester combinations, Vernal (or the abn2 homozygote bred here) and Ldn (or the abn1 homozygote) respectively can be used to determine the presence of $a b n 1$ and $a b n 2$ genes. For striato-virescence, we need to breed a tester set, sv 1 and $s v 2$ homozygotes, from the present $s v$ homozygote.

The efficiency of using this type of gene system, i. e., duplicated recessive genes, in phylogenetic studies is much lower than using the complementary gene systems because genotype determination only is possible by observing $\mathrm{F}_{2}$ segregation which requires additional generation time and a large number of offspring for segregation detection. A presumed advantage is the probable existence of a greater number of duplicated recessive gene systems in polyploid wheats as compared to complementary gene systems. This is suggested by the fact that all three chlorophyll abnormalities studied are controlled by this type of gene system.

\section{Limitation of aneuploid analysis of using DS lines} for characters controlled by duplicated recessive genes. In common wheat, monosomic analysis that uses a complete series of 21 monosomics (Sears, 1954), has proved a simple, very effective means of determining the chromosomal locations of genes for a variety of characters. In Emmer wheat, Mochizuki (1968) produced a similar monosomic series. Its use in the gene analysis of Emmer wheat, however, is limited because recovery of monosomics in the offspring averaged only $11 \%$ for all the 
monosomics compared to the ca. $75 \%$ for common wheat offspring. No monosomic analysis therefore has been conducted with the Mochizuki's series. The set of DS lines of Ldn wheat produced by Joppa and Williams (1988) provides an alternative means of aneuploid analysis. Konzak and Joppa (1988) first used the set in their gene analysis of chocolate chaff in durum wheat and successfully located the responsible recessive gene, $c c$, on chromosome 7B of that wheat and its suppressor (wildtype homoeoallele) on 7D of CS. My previous work on Type 2 hybrid chlorosis, in which Ldn DS lines were used, also was successful in locating Cs1 on chromosome 5A of Emmer wheat and Cs2 on chromosome 4G of Timopheevi wheat (Tsunewaki, 1992).

In contrast, the present findings on the chromosomal bases of three chlorophyll abnormalities are somewhat ambiguous, because all are controlled by duplicated recessive genes plus their wild-type homoeoalleles present on a D-genome chromosome of CS. As for the striato-virescence (sv) controlled by the duplicated loci $s v 1$ and $s v 2$, there is certainty that the location of the $s v 1$ gene is on chromosome $3 \mathrm{~A}$, whereas the location of sv2 on chromosome 2A was deduced from a higher frequency of $\mathrm{sv}$ plants in offspring of the $2 \mathrm{D}(2 \mathrm{~A})$ line than in those of the $2 \mathrm{D}(2 \mathrm{~B})$ line, despite the fact that both carry the same suppressor, $S v 3$, on their 2D chromosomes.

Delayed virescence (dv) also was shown to be controlled by the duplicated recessive genes $d v 1$ and $d v 2$. The $d v$ homozygote and Ldn differ in a single gene pair on their $2 \mathrm{~B}$ chromosomes; the former has the $d v 1$ allele, the latter the $D v 1$ allele. Direct evidence also indicated that chromosome 2D of CS carries its wild-type homoeoallele, Dv3. $\mathrm{F}_{2}$ data for the cross Ldn $\mathrm{x}$ Vernal show that each parent has one duplicated recessive gene, $d v 1$ or $d v 2$. Because Ldn was shown to carry $D v 1$ gene, this wheat was deduced as having the $d v 2$ gene and Vernal $d v 1$. The chromosome location of the $d v 2$ locus is not clear from these findings. Based on the homoeology of chromosomes $2 \mathrm{~B}$ and $2 \mathrm{D}$, which respectively carry the $d v 1$ and $d v 3$ loci, I assumed that the third locus, $d v 2$, may be on the remaining group 2 chromosome, $2 \mathrm{~A}$.

As for albino (abn), both the allelism test results for the $a b n$ homozygotes and the $\mathrm{F}_{2}$ data for the cross Ldn $\mathrm{x}$ Vernal indicated that this character also is controlled by two recessive genes, $a b n 1$ and $a b n 2$, and that Ldn carries the former and Vernal the latter gene. Aneuploid analysis of a fixed line for the $a b n 2$ gene showed that the $2 \mathrm{~A}$ chromosome of that line carries the $a b n 1$ gene and that chromosome 2D of CS carries its wild-type homoeoallele, Abn3. Evidence for the $a b n 2$ gene being on chromosome $2 \mathrm{~B}$ is indirect. $\quad \mathrm{F}_{2}$ progenies of the $\mathrm{DS} 2 \mathrm{D}(2 \mathrm{~B})$ line segregated abn plants at a high frequency than those of the DS $2 \mathrm{D}(2 \mathrm{~A})$ line, being similar to that of the control $\mathrm{F}_{2}$ 's, although this line carries the suppressor Abn3 on its chromosome 2D.
All the findings indicate that aneuploid analysis of Emmer wheat done with a set of Ldn DS lines is limited for making a clear-cut determination of the carrier chromosomes of duplicated recessive genes, in particular when a D-genome chromosome carries the wild-type homoeoallele. Taking into account this limitation, at present the set of Ldn DS lines is the only useful means of determining the chromosomal position of genes in this wheat group.

The task of breeding $a b n$ homozygotes was done with the help of Kenji Ichikawa, Imari Oda and Kayoko Morinaga, to whom I express my deepest gratitude. I also am grateful to L. R. Joppa, North Dakota State University, for his kindness in supplying the disomic substitution lines of Langdon durum, thereby facilitating the investigation reported here.

\section{REFERENCES}

Frankel, O. H. (1950) A polymeric multiple gene change in hexaploid wheat. Heredity 4, 103-116.

Hermsen, J. G. Th. (1963) Sources and distribution of the complementary genes for hybrid necrosis in wheat. Euphytica 12, 147-160.

Joppa, L. R. and Williams, N. D. (1988) Langdon durum disomic substitution lines and aneuploid analysis in tetraploid wheat. Genome 30, 222-228.

Konzak, C. F. and Joppa, L. R. (1988) The inheritance and chromosomal location of a gene for chocolate chaff in durum wheat. Genome 30, 229-233.

McIntosh, R. A., Hart, G. E., Devos, K. M., Gale, M. D., and Rogers, W. J. (1998) Catalogue of gene symbols for wheat. In: Proceedings of the 9th International Wheat Genetics Symposium, Saskatoon, Vol. 5 (ed.: A. E. Slinkard), pp. 1-235. University Extension Press, University of Saskatchewan, Saskatoon.

Miller, T. E. and Koebner, R. M. D. (eds.) (1988) Proceedings of the 7th International Wheat Genetics Symposium, Vol. 2, pp.1211. Institute of Plant Science Research, Cambridge.

Mochizuki, A. (1968) The monosomics of durum wheat. In: Proceedings of the 3rd International Wheat Genetics Symposium, Canberra (eds.: K. W. Finlay, and K. W. Shepherd), pp.310-315. Butterworths, Sydney.

Nishikawa, K. (1986) Development of telosomic 2B line in Emmer wheat. Japan. J. Breed. Vol. 36, Suppl. No. 2, 6465.

Sears, E. R. (1954) The aneuploids of common wheat. Res. Bull. Mo. Agr. Exp. Stat. No. 572, pp. 59.

Tsunewaki, K., (1960) Monosomic and conventional gene analyses in common wheat. III. Lethality. Jpn. J. Genet. 35, 7175 .

Tsunewaki, K. (1992) Aneuploid analyses of hybrid necrosis and hybrid chlorosis in tetraploid wheats using the D genome chromosome substitution lines of durum wheat. Genome 35, 594-601.

Tsunewaki, K., and Nakai, Y. (1973) Considerations on the origin and speciation of four groups of wheat from the distribution of necrosis and chlorosis genes. In: Proceedings of the 5th International Wheat Genetics Symposium, Missouri (eds.: E. R. Sears, and L. M. S. Sears), pp.123-129. Missouri Agricultural Experiment Station, Missouri. 